\title{
REPERCUSSÃO GERAL NO RECURSO EXTRAORDINÁRIO E TERCEIROS INTERESSADOS À LUZ DA JURISDIÇÃO CONSTITUCIONAL
}

\author{
EXTRAORDINARY APPEAL'S GENERAL REPERCUSSION AND THIRD PARTIES \\ IN THE CONSTITUTIONAL JURISDICTION
}

\author{
${ }^{1}$ Edilene Lôbo
}

\section{RESUMO}

A repercussão geral, objetivando combater excesso de recursos extraordinários e conferir unidade à jurisprudência por meio de decisões seriais, revela importante técnica viabilizadora de direitos coletivos. Entretanto, a recente legislação processual atribuiu a competência para apreciá-la, no exercício do juízo de admissibilidade do recurso extraordinário, aos tribunais recorridos, retirando-a do Supremo Tribunal Federal, bem como só admite entidades ou órgãos como terceiros interessados no seu julgamento. Esse quadro contraria o paradigma da processualidade constitucional democrática, assinalando o objetivo deste trabalho, que é redesenhá-lo a partir da teoria da sociedade aberta de intérpretes e do processo como teoria da decisão democrática.

Palavras-chave: Repercussão geral, Recurso extraordinário, Participação dos intérpretes, Processualidade democrática

\begin{abstract}
General repercussion, aiming to fight excess of extraordinary appeals and unifying jurisprudence through serial rulings, reveals an essential technique to make collective rights feasible. However, recent procedural legislation gave powers to decide on the matter (exercising the admissibility appraisal of the extraordinary appeal) to the lower courts, taking it from the Brazilian Supreme Court, at the same time only accepting organizations as thirdparties. This situation goes against the Democratic Constitutional Procedure paradigm, signaling this work's goal: to redesign the situation starting from the Open Society of Interpreters theory and from the legal procedure as a theory of the democratic ruling.
\end{abstract}

Keywords: General repercussion, Extraordinary appeals, Interpreter's participation, Democratic legal procedure

\footnotetext{
${ }^{1}$ Doutora em Direito Processual pela Pontifícia Universidade Católica - PUC, Belo Horizonte, Minas Gerais, (Brasil). Professora do Mestrado e da Graduação em Direito pela Universidade de Itaúna, Minas Gerais. E-mail: tutortreinamento@gmail.com
} 


\section{INTRODUÇÃO}

Os ideais de igualdade e justiça, entendidos, respectivamente, como vedação à discriminação e atuação concreta do ordenamento jurídico, passam pela compreensão de que não pode haver condutas fora da lei e da Constituição, raciocínio que se estende para a impossibilidade de tratar direitos fundamentais sem processo. Este, por sua vez, sem participação dos interessados, se desnatura e abre caminho para a discricionariedade, combalindo a teoria da democracia.

Nesse contexto se apresenta a repercussão geral da matéria constitucional, como requisito de admissibilidade do recurso extraordinário, prevista no parágrafo $3^{\circ}$ do artigo 102 da Constituição Federal, cujo pretexto para sua introdução no ordenamento constitucional, como exposto nos motivos da Emenda Constitucional $n^{\circ} 45$, foi modernizar o aparelho judicial estatal, "com a consciência de que os juízes fazem parte da comunidade e que somente enquanto partícipes dessa mesma comunidade, podem distribuir Justiça” (BRASIL, 2004).

Menos com o objetivo de distribuir justiça e mais com a finalidade de estancar o fluxo intenso de recursos, copiando modelo da Suprema Corte dos Estados Unidos da América, a repercussão geral veio como filtro de acesso ao Supremo Tribunal Federal, na tentativa de lhe manter com feição de corte constitucional, sem a obrigatoriedade de apreciar a conflituosidade ordinária e, ainda, conferindo o formato objetivo do recurso extraordinário.

A repercussão geral, por envolver "questões relevantes do ponto de vista econômico, político, social ou jurídico, que ultrapassem os interesses subjetivos do processo", sempre tratará de direitos coletivos em sentido amplo ou restrito, como se tem do caput do artigo 1.035 do Novo Código de Processo Civil (BRASIL, 2015).

O Novo Código de Processo Civil, em sua versão original, no parágrafo único do artigo 1.030 (BRASIL, 2015), estabelecia que, independente do juízo de admissibilidade, depois da oferta de contrarrazões, o recurso extraordinário seria remetido ao Supremo Tribunal Federal sem represamentos, reafirmando a competência exclusiva desse órgão para apreciar a repercussão geral, que só poderia ser afastada por dois terços de seus membros, dando ecos ao $\S 2^{\circ}$ do artigo 102 da Constituição Federal (BRASIL, 1988).

Antes mesmo de ser aplicada, com a recente modificação trazida pela Lei $\mathrm{n}^{\circ} 13.256$, de 05 de fevereiro de 2016 (BRASIL, 2016), houve transferência dessa competência para o presidente ou vice-presidente do tribunal recorrido, restabelecendo a redação anterior, em 
retrocesso de altissonante inconstitucionalidade dos incisos I e V do modificado artigo $1.030^{1}$ (BRASIL, 2015).

O juízo de admissibilidade do recurso extraordinário, como posto nessa nova redação, não encontra guarida na Constituição Federal, pelo que deve ser-lhe negada aplicação, porque, no $\$ 3^{\circ}$ do artigo 102 desse diploma fundamental (BRASIL, 1988), a competência é exclusiva, inarredável e por maioria qualificada, exigente de quórum mínimo de dois terços dos membros do Supremo Tribunal Federal. Por outro ângulo, é contraproducente, porque, inadmitido o recurso extraordinário, caberá agravo, o que obrigará reanálise da questão pelo Supremo Tribunal Federal, aumentando o número de recursos e o consequente consumo de tempo e dinheiro. Sob o aspecto da possibilidade da formação de consensos na busca da unidade jurisprudencial, também é um desserviço, porque, sem os caminhantes não se constrói o caminho, quer dizer, sem os sujeitos do processo democrático, não é possível falar em jurisdição válida.

É bom repetir que o julgamento da repercussão geral é capaz de multiplicar a atividade judicial de maneira exponencial, eis que o impacto sobre recursos que estejam em trâmite é imediato, incidindo sobre jurisdição de outros órgãos, como estabelece o artigo 1.035, § 5 , do Novo Código de Processo Civil (BRASIL, 2015). O inverso, negada a repercussão geral, da mesma forma, impede seguimento aos recursos que contenham temas semelhantes, também em efeito cascata, consoante artigo 1.035, $\S 8^{\circ}$, do Novo Código de Processo Civil (BRASIL, 2015).

Essa expansão da decisão que envolve a repercussão geral, que toca direitos de toda a coletividade, realça a participação de terceiros interessados como condição de procedibilidade e de legitimidade do provimento daí advindo. Por essa classe de direitos envolvidos, de lege

1 Art. 1.030. Recebida a petição do recurso pela secretaria do tribunal, o recorrido será intimado para apresentar contrarrazões no prazo de 15 (quinze) dias, findo o qual os autos serão conclusos ao presidente ou ao vicepresidente do tribunal recorrido, que deverá:

I - negar seguimento:

a) a recurso extraordinário que discuta questão constitucional à qual o Supremo Tribunal Federal não tenha reconhecido a existência de repercussão geral ou a recurso extraordinário interposto contra acórdão que esteja em conformidade com entendimento do Supremo Tribunal Federal exarado no regime de repercussão geral;

b) a recurso extraordinário ou a recurso especial interposto contra acórdão que esteja em conformidade com entendimento do Supremo Tribunal Federal ou do Superior Tribunal de Justiça, respectivamente, exarado no regime de julgamento de recursos repetitivos;

(...)

V - realizar o juízo de admissibilidade e, se positivo, remeter o feito ao Supremo Tribunal Federal ou ao Superior Tribunal de Justiça, desde que:

a) o recurso ainda não tenha sido submetido ao regime de repercussão geral ou de julgamento de recursos repetitivos;

b) o recurso tenha sido selecionado como representativo da controvérsia; ou

c) o tribunal recorrido tenha refutado o juízo de retratação. 
lata, o $\$^{\circ}$ do artigo 1.035 do Novo Código de Processo Civil (BRASIL, 2015) preconiza, “na análise da repercussão geral, a manifestação de terceiros, subscrita por procurador habilitado." Não se tem aqui, como lido, qualquer outro elemento qualificador desses terceiros interessados, embora se possa complementá-lo com o artigo 983 do Novo Código de Processo Civil (BRASIL, 2015), como se comentará adiante.

É bem verdade que a primeira parte do $\$ 4^{\circ}$ do artigo 1.035 do Novo Código de Processo Civil (BRASIL, 2015) contém o verbo "poderá", atribuído ao relator, para admitir o terceiro interessado. Todavia, é justamente na direção da obrigatoriedade que a perspectiva da soberania popular irradiante dos poderes estatais democráticos impõe a transformação de faculdade em dever. Destaca-se, para a correta aplicação desse dispositivo, a viragem hermenêutica anunciada desde a Emenda Constitucional n 45 (BRASIL, 2004), para tornar o juiz participante da comunidade aberta a todos os intérpretes, propiciando carga e retrocarga democrática da sua função, buscando eficiência e formação de consensos.

Tal qual dispõe o Novo Código de Processo Civil (BRASIL, 2015), à guisa de regular a manifestação do terceiro interessado na repercussão geral, o Regimento Interno do Supremo Tribunal Federal (BRASIL, 2015), no artigo 323, $\S 3^{\circ}$, estabeleceu que o relator ou relatora poderá, mediante decisão irrecorrível, admiti-la de ofício ou a requerimento, em prazo que fixar.

Esses normativos são problemas a serem corrigidos, padecendo de inconstitucionalidades gritantes, merecendo a releitura apresentada pelo presente trabalho, a começar pela suposta liberdade do relator, como se a admissão de terceiros não viesse da classe de direitos envolvidos, associada ao paradigma democrático, e lhe fossem conferidas faculdades aleatórias. Noutro ponto, a pretendida irrecorribilidade da decisão venda o ato estatal, impedindo controle do ofício judicante.

Daí o objetivo do presente artigo, oferecendo proposta de revisão da procedimentalidade para apreciação da repercussão geral, tendo em mira a preservação da cártula de direitos coletivos. Esse objetivo, com efeito, se volta para a implementação do direito de argumentação dos interessados nos provimentos judiciais coletivos, reforçando a democracia participativa, na medida em que se dá a abertura hermenêutica do Supremo Tribunal Federal a todos aqueles que desejarem participar do processo de interpretação do ordenamento jurídico.

Assim, a repercussão dos temas versados por meio do recurso extraordinário - que acabou por também lhe inserir no rol de direitos coletivos, eis que invoca participação coletiva no seu iter de formação - exige que sua apreciação escape dos velhos padrões 
formalistas, solipsistas e afastados do controle público na construção da decisão final que trata o que é de todos. Essa posição reforça a noção de que a efetividade desses importantes direitos humanos passa pela ampliação dos processos participativos, que lhe dá base fundante, justificando a importância do temário aqui debatido.

Para alcançar as conclusões oferecidas, adotou-se metodologia de revisão da legislação e da jurisprudência, contrapondo-as ao estado da arte para selecionar posicionamentos doutrinários que franqueiem a crítica, apoiada na compreensão do processo como base democrática da decisão, para que o combate à desigualdade e a busca por um Brasil mais justo, com a implementação dos direitos coletivos, tenha como eixo a aplicação das leis processuais pelas lentes da Constituição, descartando-se aqueles dispositivos que violem suas regras e princípios.

\section{O DEBATE dOS DIREITOS COLETIVOS PELA TÉCNICA DA REPERCUSSÃo GERAL}

Com a inserção da repercussão geral no recurso extraordinário, houve a mutação desse apelo para tratar da generalidade dos direitos envolvidos no thema decidendum, ainda que versado por particular, cuja decisão tem efeitos nas demandas paralelas, servindo de modelo para casos futuros.

É sobre a generalidade dos direitos discutidos na repercussão geral, impactando direitos de toda a comunidade, ganhando contornos de processo coletivo especial, de modo a permitir julgamento objetivo, que se desenvolve o raciocínio da obrigatoriedade de participação do cidadão na formação desse convencimento.

Lançando mão da classificação de Daniel Amorim Assumpção Neves para o controle concentrado de constitucionalidade, no que denominou de processo coletivo especial, é que se buscam similitudes com a jurisdição exclusiva do Supremo Tribunal Federal na repercussão geral. Como disse, embora tratando das ações constitucionais - mas que bem pode se aplicar à repercussão geral - o bem da vida tutelado é um "sistema jurídico constitucionalmente coeso" (ASSUMPÇÃO, 2014, p. 57). Essa coesão exige que se mantenha a boa aplicação processual da técnica do recurso extraordinário, estampada na própria Constituição.

O direito de acessar a jurisdição específica pela via do recurso extraordinário, cujo requisito preambular é a demonstração da repercussão geral do tema debatido, como dito, está previsto diretamente no texto constitucional, no artigo 102, inciso III (BRASIL, 1988), limitando a argumentação recursal à decisão que contrariar a Constituição, declarar a 
inconstitucionalidade de tratado ou lei federal, julgar válida lei ou ato de governo local em face da Constituição e julgar válida lei local em face de lei federal, reprisando o objeto jurídico desse tipo de apelo: a proteção da norma fundamental, mantendo a coesão do sistema jurídico.

Humberto Theodoro Júnior reforça essa tese e salienta que o recurso extraordinário é criação do direito brasileiro, mas inspirado no Judiciary Act do modelo norte-americano, cuja "finalidade é manter, dentro do sistema federal e da descentralização do Poder Judiciário, a autoridade e a unidade da Constituição" (THEODORO JR., 2016, p. 1089)

\footnotetext{
Trata-se de um recurso excepcional, admissível apenas em hipóteses restritas, previstas na Constituição com o fito específico de tutelar a autoridade e aplicação da Carta Magna. Dessas características é que adveio a denominação de "recurso extraordinário", adotada inicialmente no Regimento Interno do Supremo Tribunal Federal, e, posteriormente, consagrado pelas diversas Constituições da República, a partir de 1934. (THEODORO JÚNIOR, 2016, p. 1090)
}

Com esse objetivo, "a comprovação da repercussão geral inaugura um novo momento de aproximação do Supremo da própria sociedade, ultrapassando o vácuo deixando pela arguição de relevância, cujo matiz antidemocrático era inegável”, como dizem Sérgio Gilberto Porto e Daniel Ustárroz ( PORTO e USTÁRROZ, 2016, p. 250).

Ocorre, porém, que o praxismo tem direcionado a técnica apenas à unidade da jurisprudência, sem compartilhamento com os variados sujeitos do processo, descartando tudo o que não se enquadrar no quanto previamente estabelecido em paradigmas. E isso, a tal ponto que, contra a própria Constituição, o $\S 3^{\circ}$ do artigo 1.035 do Novo Código de Processo Civil (BRASIL, 2015) reduziu a duas as hipóteses em que haverá repercussão geral: quando o recurso impugnar acórdão que contrarie súmula ou jurisprudência dominante do Supremo Tribunal Federal e/ou que tenha reconhecido a inconstitucionalidade de tratado ou de lei federal.

O silêncio eloquente no que tange à contrariedade da Constituição como hipótese óbvia de repercussão geral causa perplexidade, mas demonstra o intento de oferecer decisões sem grandes reflexões teóricas.

O que se observa, com esse estado de coisas, é a tendência de fixação de consensos artificiais, oriundos de autoridades impermeáveis ao debate democrático, desatentas às admoestações dos processualistas acordes ao paradigma invocado neste trabalho. 


\begin{abstract}
panorama macroestrutural estatal e jurídico, na busca de soluções técnicas consentâneas com os avanços dos direitos ocorridos desde o segundo pós-guerra nos países europeus e desaguando em nosso país após 1988.

É a partir desse pressuposto que se utiliza o processualismo constitucional democrático como uma concepção teórica que busca a democratização processual civil mediante a problematização das concepções de liberalismo, socialização e pseudossocialização processual (neoliberalismo processual) e da percepção do necessário resgate do papel constitucional do processo como mecanismo de formação das decisões, a partir do necessário aspecto comparticipativo e policêntrico das estruturas formadoras d decisões

Tal processualismo científico, revigorado pelas concepções constitucionalizantes, passa a se preocupar com um viés mais panorâmico da aplicação do direito, de modo a suplantar a mera análise das legislações processuais e investindo na compreensão dos fundamentos estatais e paradigmáticos de problemas envolvendo a própria concepção do processo e da jurisdição, mas, também, do Estado Democrático, das litigiosidades e da leitura dos direitos fundamentais. (NUNES, BAHIA, CÂMARA e SOARES, 2013, P. 40-41)
\end{abstract}

Exatamente na contracorrente da massificação das decisões sem as necessárias reflexões macroestruturais é que a manifestação dos interessados deve ser defendida, ademais de permitir concreção ao direito de participação nos provimentos judiciais, objetivando influenciar o discurso de aplicação, conferindo-lhes legitimidade e validade. Desse modo, é também um direito coletivo.

Todavia, a eficácia da intervenção de terceiros na repercussão geral, como viabilizadora da construção participada das decisões do Supremo Tribunal Federal, pluralizando e democratizando o debate dos direitos coletivos, passa pela correção da definição desses sujeitos e seus respectivos horizontes processuais. Exatamente nesse passo, Eugênio Pacelli defende que o processo "se impõe como espaço e ambiente deliberativo (democrático, nesse sentido), no qual se permite a ampla participação dos atores designados em lei e na Constituição da República (...) na construção da decisão final.” (OLIVEIRA, 2013, p. 96).

\title{
2 VARIEDADE DOS TERCEIROS INTERESSADOS NA REPERCUSSÃO GERAL
}

Tradicionalmente, o terceiro não é parte da relação processual, mas tem interesse jurídico em decorrência do vínculo que possa manter com o objeto da lide ou com as partes litigantes. No artigo 76, inciso III, do Novo Código de Processo Civil, o terceiro interessado é passível de ser excluído ou declarado revel no processo, "dependendo do polo em que se encontre" (BRASIL, 2015). Esse dispositivo está inserido no Capítulo I do Título I do Livro III, que trata dos "sujeitos do processo" (BRASIL, 2015), o que permite concluir que o terceiro interessado integra essa categoria, podendo defender seus interesses amplamente. 
O terceiro interessado na repercussão geral, entretanto, é tratado pelo Supremo Tribunal Federal como amicus curiae, compreensão que extraiu do controle concentrado de constitucionalidade, com o papel de mero auxiliar, sem grandes possibilidades argumentativas, embora se lhe defira a possibilidade falar por meio de memoriais e produzir sustentação oral durante a sessão de julgamento.

Ao fazê-lo, afirma que esse instituto só contempla entidades ou órgãos, vedando a implementação da anunciada viragem hermenêutica que permitiria apertar os laços entre juízes e cidadãos, dificultando a superação da "grave questão pertinente à legitimidade democrática das decisões emanadas desta Suprema Corte, quando no desempenho de seu extraordinário poder de efetuar, em abstrato, o controle concentrado de constitucionalidade" (BRASIL, 2000).

Invocando a sociedade aberta de intérpretes, teorizada por Peter Häberle, o Ministro Gilmar Mendes, em voto proferido no julgamento da ADI n² 2316, afiançou a importância da participação para a construção de decisões legítimas e tecnicamente bem fundamentadas.

\begin{abstract}
Não há dúvida, outrossim, de que a participação de diferentes grupos em processos judiciais de grande significado para toda a sociedade cumpre uma função de integração extremamente relevante no Estado de Direito. A propósito, Peter Häberle defende a necessidade de que os instrumentos de informação dos juízes constitucionais sejam ampliados, especialmente no que se refere às audiências públicas e às "intervenções de eventuais interessados", assegurando-se novas formas de participação das potências públicas pluralistas na qualidade de intérpretes em sentido amplo da Constituição (cf. Häberle, Peter. Hermenêutica Constitucional. A Sociedade Aberta dos Intérpretes da Constituição: ontribuição para a Interpretação Pluralista e "Procedimental" da Constituição. Tradução de Gilmar Mendes. Porto Alegre, 1997, p. 47-48). Ao ter acesso a essa pluralidade de visões em permanente diálogo, esse Supremo Tribunal Federal passa a contar com os benefícios decorrentes dos subsídios técnicos, implicações político-jurídicas e elementos de repercussão econômica que possam vir a ser apresentados pelos "amigos da Corte". Essa inovação institucional, além de contribuir para a qualidade da prestação jurisdicional, garante novas possibilidades de legitimação dos julgamentos do Tribunal no âmbito de sua tarefa precípua de guarda da Constituição. (BRASIL, 2010)
\end{abstract}

A despeito dessa veemência, a base justificativa do discurso de aplicação para a intervenção de terceiros são as Leis no 9868 e 9882, respectivamente de 10 de novembro e de 03 de dezembro de 1999, que não preveem a inclusão do cidadão. Corroborando, confira-se a decisão prolatada pelo Ministro Edson Fachin, no Recurso Extraordinário no 596.701, originário de Minas Gerais (BRASIL, 2015).

Nesse caso, depois de deferir o ingresso de entidade associativa de militares da reserva e pensionistas na condição de amicus curiae, o Ministro Relator indeferiu o pedido de intervenção de Walter de Almeida, José Augusto de Souza Santos, José Sebastião da Cruz e 
Caetano Celeste, argumentando que "somente podem figurar como amicus curiae órgãos ou entidades, não se admitindo até o presente momento, pessoas físicas sob essa condição.” (BRASIL, 2015)

O que justifica tal posição?

Explica o Ministro que seria pela adoção dos critérios de "relevância da matéria, a representatividade dos postulantes e serem os requerentes órgãos e entidades", se limitando mesmo a conferir a natureza jurídica, representativa de grupos econômicos e/ou profissionais, da pessoa que requer a intervenção.

\begin{abstract}
A relevância da matéria se verifica a partir de sua amplitude, bem assim a respectiva transcendência, e de sua nítida relação com as normas constitucionais. A representatividade do 'amigo da Corte' está ligada menos ao seu âmbito especial de atuação, e mais à notória contribuição que ele pode trazer para o deslinde da questão. Por fim, é cediço o entendimento deste Supremo Tribunal Federal de que somente podem figurar como amicus curiae órgãos ou entidades, não se admitindo, até o presente momento, pessoas físicas sob essa condição

Nesse sentido, cito as seguintes decisões monocráticas: RE 724.347-ED (rel. min. Roberto Barroso, DJe de 08.06.2015), RE 590.415 (rel. min. Roberto Barroso, DJe de 16.12.2014), RE 631.053 (rel. min. Celso de Mello, DJe de 16.12.2014), RE 608.4082 (rel. min. Teori Zavascki, DJe de 08.09.2014), ADI 4874 (rel. min. Rosa Weber, DJe de 03.10.2013), RE 566.349 (rel. min. Cármen Lúcia, DJe de 06.06.2013) e ADI 4264 (rel. min. Ricardo Lewandowski, DJe de 31.08.2011).

A AMIRPEM representa militares inativos e pensionistas em todo o território nacional. Desse modo, exibe evidente representatividade, tanto em relação ao âmbito espacial de sua atuação, quanto em relação à matéria em questão. Dessa maneira, sua atuação no feito tem a possibilidade de enriquecer o debate e, assim, auxiliar a Corte na formação de sua conviç̧ão.

Por outro lado, não obstante a relevância e o interesse dos Peticionantes pessoas físicas em relação ao deslinde da demanda, não se verifica, em concreto, a excepcionalidade das razões que justifiquem a intervenção no feito como terceiros interessados. Afinal, a própria instituição da repercussão geral pressupõe a transcendência subjetiva de seus efeitos a todos os outros litigantes que estejam na mesma situação jurídica extraída do recurso-paradigma. (BRASIL, 2015)
\end{abstract}

Essa posição, que reconhece "a relevância e o interesse dos Peticionantes", mas não lhes dá voz, está dissociada do pensamento de Peter Häberle, defensor da interpretação constitucional adequada à sociedade pluralista e multifacetada (HABERLE, 1997). Aliás, o Ministro Gilmar Mendes, ao apresentar a obra de Peter Häberle, pontifica a balizas mais adequadas para as premissas formadoras do processo na democracia, afirmando que "todo aquele que vive a Constituição é seu legítimo intérprete" (HABERLE, 1997, p. 9).

Por que, então, a exclusão do cidadão como amigo da Corte?

Quem falará pelas minorias, a se ter em conta que os órgãos ou entidades admitidos se voltam para a representação de grupos e categorias profissionais ou economicamente organizadas? 
Essas indagações buscam afirmar a jurisdição como atividade da democracia numa sociedade aberta para atuação concreta dos direitos coletivos, por meio do devido processo constitucional.

Por sua vez, tais inferências, feitas a partir da posição do Supremo Tribunal Federal, indicam ser falseável a exclusão do cidadão dos processos coletivos no paradigma da democracia participativa, porque o que qualifica o terceiro interessado apto ao debate é a classe de direitos e sua condição de sujeito do processo, juridicamente interessado no resultado, jamais sua condição econômica ou organizacional.

Corroborando, a se ter em conta a redação do artigo 983 do Novo Código de Processo Civil: “O relator ouvirá as partes e os demais interessados, inclusive pessoas, órgãos e entidades com interesse na controvérsia, que, no prazo comum de 15 (quinze) dias, poderão requerer a juntada de documentos, bem como as diligências necessárias para a elucidação da questão de direito controvertida" (BRASIL, 2015). Estes, portanto, os horizontes processuais dos terceiros interessados, pessoa físicas, órgãos ou entidades.

\subsection{Recorribilidade da Decisão que Inadmitir o Terceiro Interessado na Repercussão Geral}

No Estado Democrático de Direito, não se pode admitir decisões estatais sem controle endógeno ou exógeno, com o risco de se implantar o arbítrio, imunizando a verificação dos móveis componentes das decisões judiciais, arrebatando a garantia de fundamentação congruente e convincente ${ }^{2}$. A propósito, bom reiterar Rui Barbosa, para se reafirmar que "onde quer que haja um direito individual violado, há de haver um recurso judicial para a debelação da injustiça”" (BARBOSA, 1892, Tomo III, v. 19, p. 42).

Com isso, é ociosa a previsão de irrecorribilidade de decisão que decidir pedido de intervenção de terceiros na repercussão geral, como se lê do Novo Código de Processo Civil e no Regimento Interno do Supremo Tribunal Federal.

\footnotetext{
${ }^{2}$ Nos termos dos incisos do $\S 1^{\mathrm{o}}$ do artigo 489 do Novo Código de Processual, não se considera fundamentada, qualquer decisão judicial que: "I - se limitar à indicação, à reprodução ou à paráfrase de ato normativo, sem explicar sua relação com a causa ou a questão decidida; II - empregar conceitos jurídicos indeterminados, sem explicar o motivo concreto de sua incidência no caso; III - invocar motivos que se prestam a justificar qualquer outra decisão; IV - não enfrentar todos os argumentos deduzidos no processo capazes de, em tese, infirmar a conclusão adotada pelo julgador; V - se limitar a invocar precedente ou enunciado de súmula, sem identificar seus fundamentos determinantes nem demonstrar que o caso sob julgamento se ajusta àqueles fundamentos; VI - deixar de seguir enunciado de súmula, jurisprudência ou precedente invocado pela parte, sem demonstrar a existência de distinção no caso em julgamento ou a superação do entendimento."
} 
A se tratar de decisão interlocutória, cabível agravo interno, como tantas vezes reconheceu o próprio Supremo Tribunal Federal, v.g. Agravo Regimental na ADI no 2.435, originária do Rio de Janeiro, relatado pela Min. Cármen Lúcia (BRASIL, 2015).

\section{A COMPETÊNCIA RECURSAL COMO DIREITO FUNDAMENTAL À PROTEÇÃO CONTRA TRIBUNAIS DE EXCEÇÃO}

Os limites da competência para atuação dos órgãos jurisdicionais são estampados na Constituição, que garante: "não haverá juízo ou tribunal de exceção" (inciso XXXVII do artigo $5^{\circ}$ ) (BRASIL, 1988). O respeito à competência dos órgãos jurisdicionais, nesse passo, é direito fundamental ao juiz natural prefixado, impondo cumprimento por todos os órgãos e agentes estatais, não podendo ser ignorado pela lei processual ou pela jurisprudência.

A competência, dessa forma, corrobora a promessa do processo justo, sendo certo que condutas tendentes a conspurcá-la, assim como decisões judiciais que a banalizem, acabam por tornar os princípios processuais desinfluentes, esbarrando nos direitos coletivos.

Sem dúvida que as razões para decidir, demonstrando o percurso teórico, fático e probatório que trilhou o julgador, também são cruciais para a legitimidade do ato. E mais que isso, essenciais para a validade do próprio ordenamento jurídico, que se faz revisto, reconstruído ou aplicado através do processo, mas, por óbvio, de nada serve a decisão fundamentada oriunda de agente incompetente e contrária à Constituição, porque a violação se perfaz no nascedouro do ato, não validando seu percurso argumentativo.

Por isso se afirma não ser possível afastar o juízo de admissibilidade da repercussão geral do Supremo Tribunal Federal, eis que matéria originalmente tratada na Constituição da República, sob pena de usurpação, ainda que se diga tratar de competência própria do tribunal de origem ${ }^{3}$.

A atribuição dessa competência aos tribunais recorridos pela regra processual criticada revela séria agressão ao devido processo legal, agravada pela limitação ainda maior à participação do cidadão na jurisdição constitucional. Haverá, pela mesma razão declinada, redução do contraditório pelo manejo dos recursos que lhe são inerentes, que compõe, com o devido processo legal, o berço da boa e devida fundamentação das decisões judiciais. Esse

\footnotetext{
${ }^{3}$ Conforme decidido pelo Supremo Tribunal Federal na Questão de Ordem no Agravo de Instrumento ${ }^{\circ}$ 760.358, originário de Sergipe, publicado em 18.02.2010, com esta ementa: “(...) Ao decretar o prejuízo de recurso ou exercer o juízo de retratação no processo em que interposto o recurso extraordinário, o tribunal de origem não está exercendo competência do STF, mas atribuição própria (...)."
} 
liame, que vincula o contraditório ao direito de acessar outras esferas de jurisdição, exige apreciação das razões trazidas pelos interessados, porquanto possibilitarão formação da correta decisão judicial, evidenciando a concretização da influência pela argumentação livre.

De posse dessas premissas, se relê a cláusula constitucional do devido processo legal, que impõe a todos os órgãos estatais o desempenho de suas funções pelos procedimentos preexistentes nas normas processuais que guardem correspondência com a Constituição, livrando-a de arranhões (BRÊTAS, 2016). Em destaque, mais uma vez, a previsão constitucional expressa para o Supremo Tribunal Federal julgar a repercussão geral. Ao fazêlo, deverá examinar as razões apresentadas com suas respectivas justificativas, sem tergiversar com o uso de fórmulas pré-fabricadas ou de bordões que nada dizem.

Exatamente para evitar que expressões esvaziadas de sentido - mero exercício de retórica a empanar a exigida prestação jurisdicional -, que se hasteia o decantado dever constitucional de fundamentação das decisões, exercitado a partir do que se apanhar da argumentação dos interessados na defesa dos direitos coletivos reclamados. Esse dever não é realizado, lado outro, com mera transcrição de decisão serial anterior que, sem qualquer juízo de ponderação, se transforma em pantomima.

Não se ignora que a remissão a outras decisões, especialmente tratando de demandas de massa, permite a motivação ad relationem. Mas, é claro, essa técnica não pode ser utilizada a ponto de a fundamentação do novo decisum ser a literalidade de decisão recorrida em outro processo envolvendo outras pessoas e circunstâncias, sem respeito à temporalidade e às balizas próprias do caso concreto.

A não ser nesse molde, se o recurso pode ser afastado sem razão nova a fundar essa iniciativa, resta configurada também a afronta ao princípio da ampla defesa e do devir processual, consignados no artigo $5^{\circ}$, inciso LIV e LV da Constituição (BRASIL, 1988), assim como, pela impossibilidade de se buscar correção em outra via, óbice do acesso ao Judiciário, eis que "a lei não excluirá da apreciação do Poder Judiciário lesão ou ameaça a direito", como se tem do inciso XXXV do artigo $5^{\circ}$ da Constituição (BRASIL, 1988).

\footnotetext{
Esses enumerados direitos e garantias fundamentais do povo, posto que estatuídos no extenso rol do art. $5^{\circ}$ da Constituição Federal vigente, são meios desenvolvidos pela técnica jurídica do Estado Democrático de Direito, com o objetivo de controlar a regularidade constitucional dos atos estatais em geral (espécie), em particular. Nesse quadro, o processo constitucional, compreendido, como já foi dito, metodologia normativa de garantia dos direitos fundamentais do povo, revela-se importante na construção do Estado Democrático de Direito, que se caracteriza política e institucionalmente como o Estado que respeita os direitos fundamentais e, ao mesmo tempo, o Estado que incentiva e concretiza a indispensável participação do povo na solução das questões que importam ao próprio Estado e à Sociedade.
} 
Dentre as relacionadas garantias constitucionais ou fundamentais sobressaem o contraditório e a fundamentação das decisões jurisdicionais que atuam na dinâmica argumentativa fática e jurídica do processo como procedimento em contraditório, de forma a permitir a geração de uma decisão jurisdicional participada e democrática, ou seja, um pronunciamento estatal decisório tecnicamente construído em conjunto pelos sujeitos do processo, quais sejam, partes e juiz. (BRÊTAS, 2016, p. 12).

\section{CONCLUSÃO}

A competência para julgar repercussão geral, carreada pelo recurso extraordinário, é exclusiva do Supremo Tribunal Federal, por determinação expressa da Constituição, havendo que se declarar a incompatibilidade dos dispositivos do Novo Código de Processo Civil, inseridos pela Lei 13.256, que dispõem de forma diversa.

O cidadão tem direito a participar do debate jurisdicional dos direitos coletivos veiculados pela repercussão geral, ao lado de órgãos e entidades, diante da promessa alumiada pela Emenda Constitucional $\mathrm{n}^{\mathbf{0}} 45$, de se implementar a sociedade aberta de intérpretes, reforçada pela garantia do processo constitucional, estruturado na principiologia que lhe dá vazão, inserto no paradigma de Estado Democrático de Direito, como teoria da decisão democrática.

Ao apreciar a repercussão geral, embora possa lançar mão de precedentes, é dever do órgão julgador declinar as razões próprias do caso sub judice, cuja concretude se apanha de suas premissas específicas, com mapeamento do genoma do fato jurídico reconstruído pela cognição, sem os subterfúgios de argumentos aleatórios.

Tanto o Código de Processo Civil, o Regimento Interno do Supremo Tribunal Federal, quanto a jurisprudência nacional, devem ser refeitos para correção da irrecorribilidade de decisões com carga judicial, em especial quando do indeferimento do pedido de intervenção de terceiros.

\section{REFERÊNCIAS}

BARBOSA, Rui. Obras completas. V. 19, Tomo III. Rio de Janeiro: Supremo Tribunal Federal, 1892. Disponível em: $<$ http://docvirt.com/docreader.net/docreader.aspx?bib=ObrasCompletasRuiBarbosa\&pasta=V ol.\%20XIX\%20(1892)\Tomo\%20III\&pesq=Peticao\%20de\%20Habeas\%20Corpus〉. Acesso em 07.abr.2016. 
BRASIL. Emenda à Constituição no 45, de 30 de dezembro de 2004. Constituição da República Federativa do Brasil. Brasilia, DF: Senado Federal, 2004. Disponível em: http://www.planalto.gov.br/ccivil_03/Constituicao/Emendas/Emc/emc45.htm. Acesso em 06 abr. 2016.

BRASIL. Constituição da República Federativa do Brasil de 1988. Brasilia, DF: Senado Federal, 1988.

Disponível

em: http://www.planalto.gov.br/ccivil_03/Constituicao/Constituicao.htm. Acesso em 31 mar. 2016.

BRASIL. Lei no 13.105, de 16 de março de 2015. Dispõe sobre o (Novo) Código de Processo Civil. Diário Oficial da União, Brasilia, DF, 17 mar. 2015. Disponível em: http://www.planalto.gov.br/ccivil_03/_ato2015-2018/2015/lei/113105.htm. Acesso em 06 abr. 2016.

BRASIL. Lei $\mathrm{n}^{\circ} 13.256$, de 05 de fevereiro de 2016. Altera a Lei ${ }^{\circ} 13.105$, de 16 de março de 2015, para disciplinar o processo e o julgamento do recurso extraordinário e o recurso especial, e dá outras providências. Diário Oficial da União, Brasilia, DF, 05 fev. 2016. Disponível em http://www.planalto.gov.br/ccivil_03/_ato2015-2018/2016/Lei/L13256.htm . Acesso em: 06 abr. 2016.

BRASIL. Supremo Tribunal Federal. Ação Direta de Inconstitucionalidade $n^{\circ}$ 2321/DF, Relator: Ministro Celso de Melo. Data do julgamento: 25 out. 2000.

BRASIL. Supremo Tribunal Federal. Ação Direta de Inconstitucionalidade nº 2316/DF, Relator: Ministro Cezar Peluso. Decisão monocrática proferida pelo Ministro Gilmar Mendes. Data do julgamento: 13 jan. 2010.

BRASIL. Supremo Tribunal Federal. Recurso Extraordinário $n^{\circ}$ 596.701/MG, Relator: Ministro Edson Fachin. Decisão monocrática de 03 set. 2015.

BRASIL. Lei $\mathrm{n}^{\circ}$ 9868, de 10 de novembro de 1999. Dispõe sobre o processo e julgamento da ação direta de inconstitucionalidade e da ação declaratória de constitucionalidade perante o Supremo Tribunal Federal. Diário Oficial da União. Brasilia, DF, 11 nov. de 1999. Acessível em: http://www.planalto.gov.br/ccivil_03/leis/L9868.htm. Acesso em: 31 mar. 2016.

BRASIL. Lei $n^{\circ}$ 9882, de 03 de dezembro de 1999. Dispõe sobre o processo e julgamento da arguição de descumprimento de preceito fundamental, nos termos do $\S 1^{\circ}$ do art. Da Constituição Federal. Diário Oficial da União. Brasilia, DF, 06 dez. de 1999. Acessível em: http://www.planalto.gov.br/ccivil_03/leis/19882.htm. Acesso em: 31 mar. 2016. 
BRASIL. Supremo Tribunal Federal. Agravo Regimental na Ação Direta de Inconstitucionalidade $n^{\circ}$ 2.435/RJ. Relatora Ministra Cármen Lúcia. Data de publicação: 26 nov. 2005.

BRASIL. Supremo Tribunal Federal. Questão de Ordem no Agravo de Instrumento ${ }^{\circ}$ 760.358/SE. Relator Ministro Gilmar Mendes. Data de publicação: 18 fev. 2010.

CANOTILHO, JJ. Gomes; MENDES, Gilmar Ferreira; SARLET, Ingo Wolfgang; STRECK, Lênio Luiz (Orgs). Comentários à Constituição do Brasil. São Paulo: Saraiva/Almedina, 2013.

CARVALHO DIAS, Ronaldo Brêtas de; SOARES, Carlos Henrique; BRÊTAS, Suzana Oliveira Marques; DIAS, Renato José Barbosa; BRÊTAS, Yvonne Mól. Estudo sistemático do NCPC com as alterações introduzidas pela Lei $N^{o} 13.256$, de 4/2/2016. 1 ed. Belo Horizonte: Editora D'Plácido, 2016.

CARVALHO DIAS, Ronaldo Brêtas; SOARES, Carlos Henrique. Novo CPC 2016. Belo Horizonte: Editora D'Plácido, 2016.

COSTA, Fabrício Veiga. Mérito Processual. A formação participada nas ações coletivas. Belo Horizonte: Arraes Editores, 2012.

CHEVALLIER, Jacques. O Estado Pós-Moderno. Editora Forum: Belo Horizonte, 2009.

DALLA-ROSA, Luiz Vergílio. Uma Teoria do Discurso Constitucional. São Paulo: Landy Editora, 2002.

DIDIER Jr. Fredie; CUNHA, Leonardo Carneiro da. Curso de Direito processual civil. 13. ed. Salvador: Editora JusPodivm, 2016.

HÄBERLE, Peter. Hermenêutica constitucional. A Sociedade Aberta dos Intérpretes da Constituição: contribuição para a Interpretação Pluralista e Procedimental da Constituição. Porto Alegre: Sergio Antônio Fabris, 1997.

OLIVEIRA, Eugênio Pacelli. Curso de Proceso Penal. 17 ed. São Paulo: Atlas, 2013.

OLIVEIRA, José do Carmo Veiga de. A Força do Efeito Vinculante No Novo CPC: Mercado, economia, globalização, sistema judiciário e direitos humanos fundamentais. 1. ed. Belo Horizonte: Editora D'Plácido, 2016.

MACIEL JÚNIOR, Vicente de Paula. Teoria das ações coletivas: as ações coletivas como ações temáticas. Editora LTR São Paulo, 2006.

MEDINA, Damares. Amicus curiae: amigo da corte ou amigo da parte? São Paulo: Saraiva, 2010. 
NEGRÃO, THEOTÔNIO; GOUVÊA, José Roberto F.; BONDIOLI, Luis Guilherme A.; FONSECA, João Francisco N. da. Código de Processo Civil e legislação processual em vigor. 47 ed. São Paulo: 2016.

NEVES, Daniel Amorim Assumpção. Manual de processo coletivo. 2. ed. São Paulo: Editora Método, 2014.

NUNES, Dierle; BAHIA, Alexandre; CÂMARA, Bernardo Ribeiro; SOARES, Carlos Henrique. Curso de direito processual civil fundamentação e aplicação. 2. ed. Belo Horizonte: Editora Fórum, 2013.

PORTO, Sérgio Gilberto; USTÁRROZ, Daniel. Manual dos recursos cíveis. 5. ed. Porto Alegre: Editora Livraria do Advogado, 2016.

ROCHA, Luciano Velasque. Ações Coletivas. O problema da legitimidade para agir. Editora Forense: Rio de Janeiro, 2007.

ROSANVALLON, Pierre. La legitimidade democrática. $1^{\mathrm{a}}$ ed. Ediciones Paidòs Ibérica: Madrid, 2010.

ROSENFELD, Michael. A identidade do sujeito constitucional, trad. De Menelick de Carvalho Netto, Mandamentos: Belo Horizonte, 2003.

SIMÕES DE TOMAZ, Carlos Alberto. Democracia e jurisdição Entre o texto e o contexto! São Paulo: Editora Baraúna, 2012.

VIOLA, Ricardo Rocha. Teoria da decisão judicial. 1. ed. Belo Horizonte: Editora D'Plácido, 2015 . 